\title{
Urban effects of Chennai on sea breeze induced convection and precipitation
}

\author{
Matthew Simpson ${ }^{1, *}$, Sethu Raman ${ }^{1}$, R Suresh ${ }^{2}$ and U C Mohanty \\ ${ }^{1}$ Department of Marine, Earth and Atmospheric Sciences, North Carolina State University, \\ Raleigh, NC 27695-8208, USA. \\ ${ }^{2}$ India Meteorological Department, Chennai. \\ ${ }^{3}$ Indian Institute of Technology, New Delhi. \\ *e-mail: msimpson@llnl.gov
}

\begin{abstract}
Doppler radar derived wind speed and direction profiles showed a well developed sea breeze circulation over the Chennai, India region on 28 June, 2003. Rainfall totals in excess of $100 \mathrm{~mm}$ resulted from convection along the sea breeze front. Inland propagation of the sea breeze front was observed in radar reflectivity imagery. High-resolution MM5 simulations were used to investigate the influence of Chennai urban land use on sea breeze initiated convection and precipitation. A comparison of observed and simulated $10 \mathrm{~m}$ wind speed and direction over Chennai showed that the model was able to simulate the timing and strength of the sea breeze. Urban effects are shown to increase the near surface air temperature over Chennai by $3.0 \mathrm{~K}$ during the early morning hours. The larger surface temperature gradient along the coast due to urban effects increased onshore flow by $4.0 \mathrm{~m} \mathrm{~s}^{-1}$. Model sensitivity study revealed that precipitation totals were enhanced by $25 \mathrm{~mm}$ over a large region $150 \mathrm{~km}$ west of Chennai due to urban effects. Deficiency in model physics related to night-time forecasts are addressed.
\end{abstract}

\section{Introduction}

The city of Chennai has grown into a large urban region since its origin as a British colony along the southeast coast of India in 1639. An estimated 7.5 million people now live within the Chennai metropolitan area making it India's fourth largest city. Chennai's city limits cover an area of $175 \mathrm{~km}^{2}$ while the metropolitan region covers an area of roughly $1200 \mathrm{~km}^{2}$. A map showing the location of Chennai along the eastern coast of India is shown in figure 1(a). The Bay of Bengal is located to the east of Chennai while the western ghats (mountains) dominate the landscape to the west.

A large portion of the annual rainfall over Chennai occurs between November and December after the onset of the Indian northeast monsoon. Less rainfall occurs during the southwest monsoon since Chennai is in a rain shadow region caused by mountains along the west coast of India. Rain occurring during the southwest monsoon is usually initiated by convergence associated with the daytime sea breeze. Simpson et al (2007) showed that approximately $75 \%$ of the rainfall over Chennai during the southwest monsoon is related to the sea breeze induced convection. Understanding the influence of large urban areas and sea breeze circulations on rainfall along the southeast coast of India is critical to the agriculture and economic interests in the region during the southwest monsoon. Studying the strength of the sea breeze is also important in forecasting the transport of pollution along coastal regions (Rhome et al 2002) and for forecasting severe weather episodes (Blanchard and Lopez 1985).

Several factors influence the strength of the sea breeze circulation and convection resulting from convergence along the sea breeze front. Shape

Keywords. Convection; sea breeze; urban heat island. 

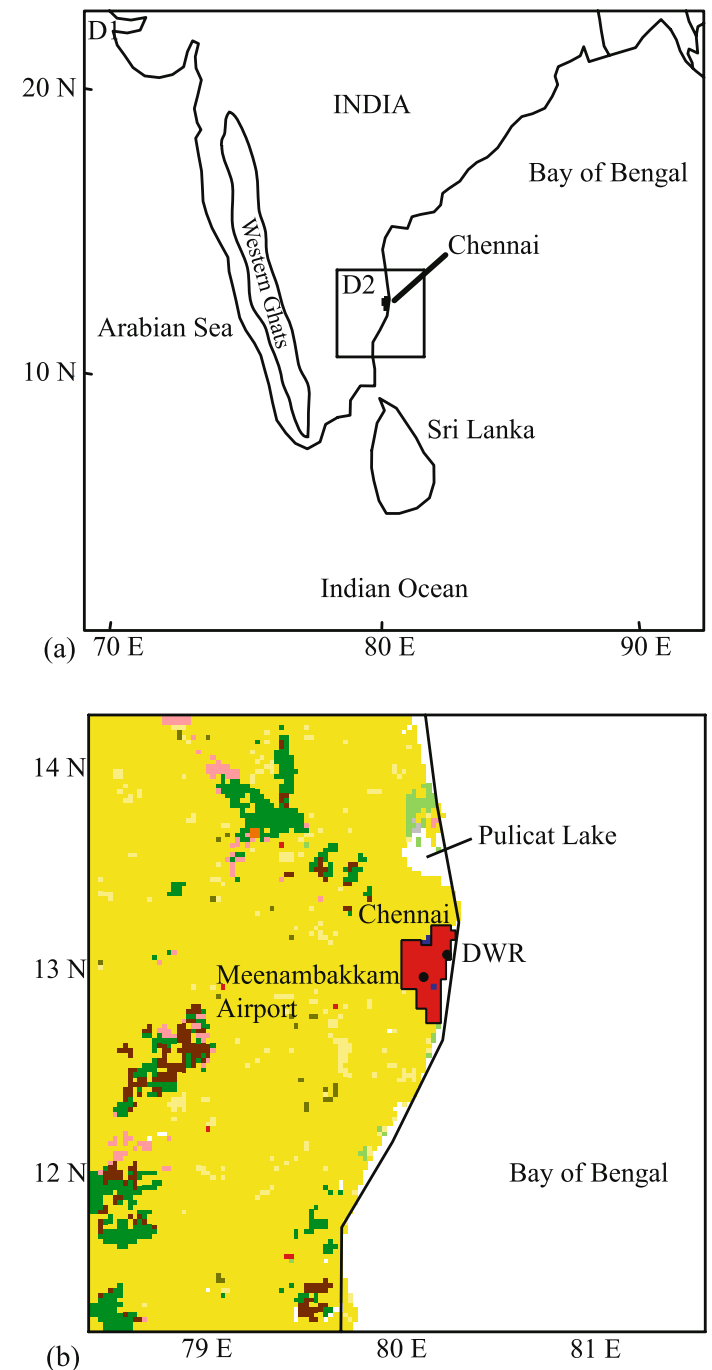

Figure 1. (a) Map showing the inner and outer domains of an MM5 simulation centered over Chennai, India. (b) Land use map of the inner model domain. Urban region of Chennai is shown in red while irrigated cropland and pasture is shown in yellow. Locations of Kalpakkam, Meenambakkam, Nungambakkam, and the Doppler Weather Radar (DWR) site.

of the coastline has been shown to affect the amount of inland convergence associated with the sea breeze. Convex coastlines have been shown to enhance inland convergence and increase convective development related to the sea breeze (Pielke 1974; Boybeyi and Raman 1992). McPherson (1970) showed that increased sea breeze divergence occurs along concave coastlines. Numerical modeling studies of the interaction between the curvature of the coastline and soil moisture variability revealed heavy precipitation to occur along the sea breeze front near the region of highest soil moisture (Baker et al 2001).

Observational and modeling studies show the mean wind flow to be important in determining the intensity of the cumulus convection associated with sea breezes during summer months (Pielke and Cotton 1977). When the mean low-level wind is in the same direction as the sea breeze, weaker convergence is observed inland along the sea breeze front (Boybeyi and Raman 1992; Atkins and Wakimoto 1997). Gilliam et al (2004) showed sea breeze fronts to propagate the furthest inland when light wind flow regimes are present.

Urban environments near the coast have been shown to influence the timing and evolution of the sea breeze. The horizontal wind speed over Tokyo is increased by $2.3 \mathrm{~m} \mathrm{~s}^{-1}$ relative to the pure sea breeze due to the presence of the urban heat island (Yoshikado 1992). Regions of enhanced vertical motion occur in a convergence zone between the sea breeze front and the urban heat island circulation (Yoshikado 1994). Numerical simulations have shown urban areas enhance convection due to increased low-level convergence associated with both sea breeze fronts and synoptic flow (Kusaka et al 2000; Ohashi and Kida 2002; Vukovich and Dunn 1978; Hjemfelt 1982; Craig and Bornstein 2002). Urban regions have also been shown to increase precipitation typically 50 to $75 \mathrm{~km}$ downwind of the city (Huff and Vogel 1978; Changnon 1979; Braham et al 1981). Rainfall amounts are usually enhanced between $5 \%$ and $25 \%$ over background values due to urban effects (Changnon et al 1981, 1991).

Chennai is one of the ideal places to study urban effects on sea breeze induced convection and precipitation because the city is a large urban region located along a straight coastline. Also during the summer months, large scale weather systems are absent in this region and the only forcing is by the sea breeze circulation. The objective of this study is to use a high-resolution numerical model to investigate urban effects on sea breeze intensity and precipitation along the Chennai coast during the Indian southwest monsoon and compare the results with observations.

\section{Model description}

The Penn State-NCAR mesoscale model, MM5 Version 3.7 (Grell et al 1994), was used in this study to understand the dynamics leading to precipitation events along the east coast of India during the southwest monsoon. A single nested model domain configuration was used as shown in figure 1(a). The outer domain is oriented to simulate the synoptic wind direction over India during the southwest monsoon. The inner domain is centered over the east coast of India near Chennai to study the influence of the daytime sea breeze on convection and precipitation. Horizontal grid spacing of the outer domain is $9 \mathrm{~km}$ and 
consists of $300 \times 300$ grid points while the inner domain has a grid spacing of $3 \mathrm{~km}$ and $127 \times 127$ grid points. A total of 41 sigma levels with vertical stretching were used for the numerical simulation. To better resolve boundary layer dynamics, nearly half of the sigma levels were located within the lowest $2 \mathrm{~km}$ of the atmosphere.

National Center for Environmental Prediction (NCEP) global final analyses (FNL) data were used to initialize the model simulation. The NCEP global analyses are archived on $1 \times 1$ degree grids and are available every six hours. Objective analysis nudging was performed every three hours using surface four-dimensional data assimilation (FDDA) during the entire simulation. The 3-D analysis was nudged every six hours using upper air data. The model was integrated for a period of 60 hours from 05:00 Indian Standard Time (IST) on 27 June to 17:00 IST on 29 June 2003. This time period was chosen because of the occurrence of a well defined sea breeze circulation on 28 June 2003 that resulted in precipitation over a large area along the east coast of India.

Thirty-second $(\sim 0.9 \mathrm{~km})$ USGS global terrain and land use data were used for the inner domain. Land use, including the location of the urban metro area of Chennai along the east coast of India, within the inner domain is shown in figure 1(b). Location of the urban region of Chennai is shown in red. The dominant land use type surrounding the metro urban area of Chennai is irrigated cropland and pasture. Locations of the Meenambakkam airport and the Doppler Weather Radar (DWR) site are also shown in figure 1(b).

The MRF planetary boundary layer (PBL) parameterization scheme was used for the MM5 simulations. MRF (Hong and Pan 1996) is a firstorder, non-local vertical diffusion scheme based on the results of large-eddy simulations. Height of the planetary boundary layer is determined by the MRF PBL scheme using a critical bulkRichardson number method where the PBL height is estimated iteratively starting from the surface. Once the counter gradient correction term has been estimated, it is possible to solve the turbulence diffusion equations for prognostic variables such as potential temperature, specific humidity, and horizontal wind components. The total flux accounts for the contribution of large-scale eddies by using a local gradient term. The MRF scheme is widely used in general circulation models and higher resolution numerical weather forecast models due to its computational efficiency and ability to resolve the influence of large-eddy turbulence.

Explicit equations for cloud water, rainwater, ice and water vapor are used by the MM5 model. Subgrid scale convection is resolved in both domains

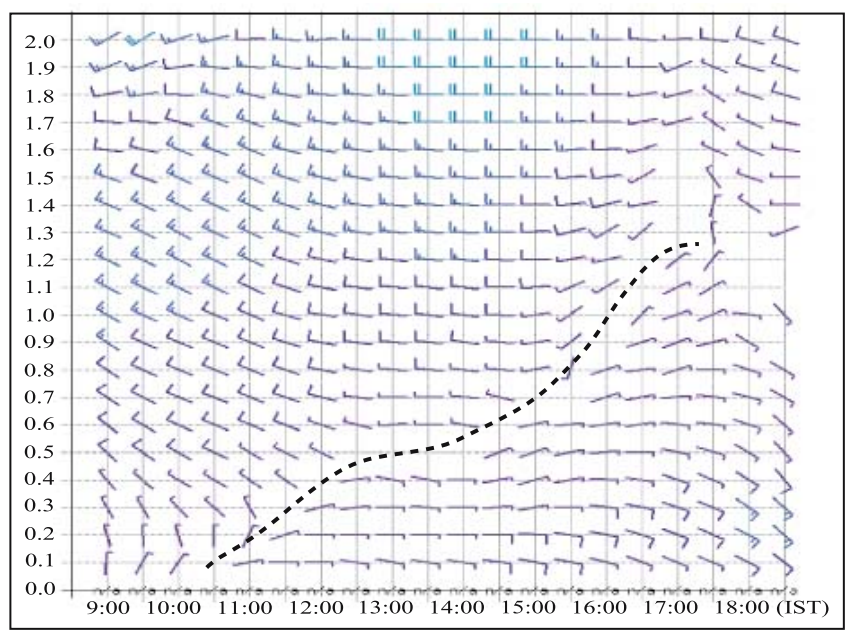

Figure 2. Radar derived wind speed and direction profiles over Chennai valid from 09:00 IST until 18:00 IST on 28 June 2003. Onshore flow near the surface associated with the sea breeze was first observed at 10:30 IST.

using the Grell cumulus parameterization (Grell et al 1994). A cumulus scheme was used in the inner domain despite the small grid spacing since the convection resulting from the sea breeze occurs on a fine scale. An initial simulation with no cumulus parameterization in the inner domain produced little explicitly resolved precipitation. Multi-level ground temperature and soil moisture are calculated using the NOAH - land surface model (Chen and Dudhia 2001).

\section{Observations of sea breeze circulation}

Radar derived wind speed and direction profiles frequently show the presence of a well developed sea breeze circulation along the Chennai coast during the Indian southwest monsoon. A time series of wind speed and direction profiles over Chennai derived from Doppler weather radar valid from 09:00 IST until 18:30 IST on 28 June 2003 is shown in figure 2. A dashed line is shown in figure 2 to mark the height of transition from onshore flow associated with the sea breeze to offshore flow. Northerly winds were observed near the surface at 09:00 IST while westerly flow was observed aloft due to the dominant monsoon flow. Onshore flow was first observed at the surface around 10:30 IST indicating a developing sea breeze circulation along the Chennai coast. Depth of the onshore flow was around $500 \mathrm{~m}$ by 13:00 IST with westerly flow still observed aloft. The depth of onshore flow associated with the sea breeze reached a maximum of roughly $1200 \mathrm{~m}$ at 17:00 IST. Onshore flow associated with a well developed sea breeze circulation was still observed at 18:30 IST. 
(a)

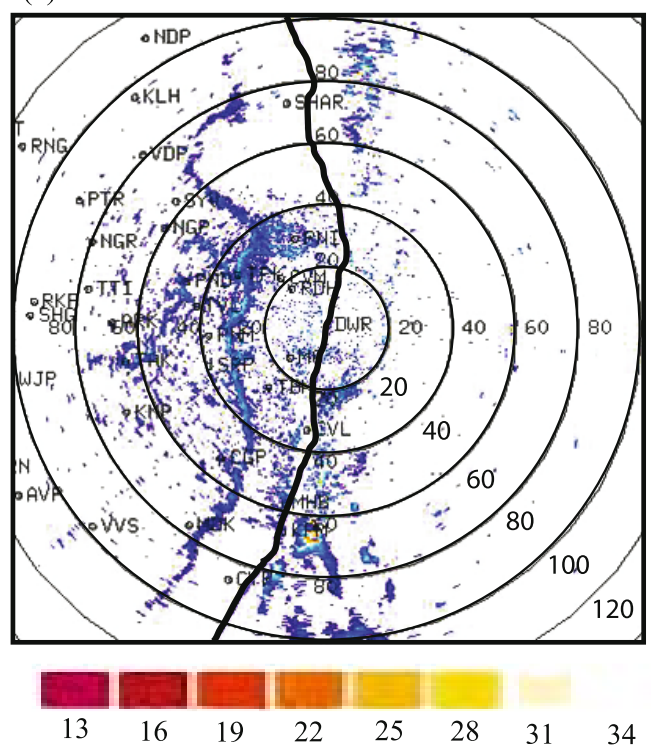

(b)

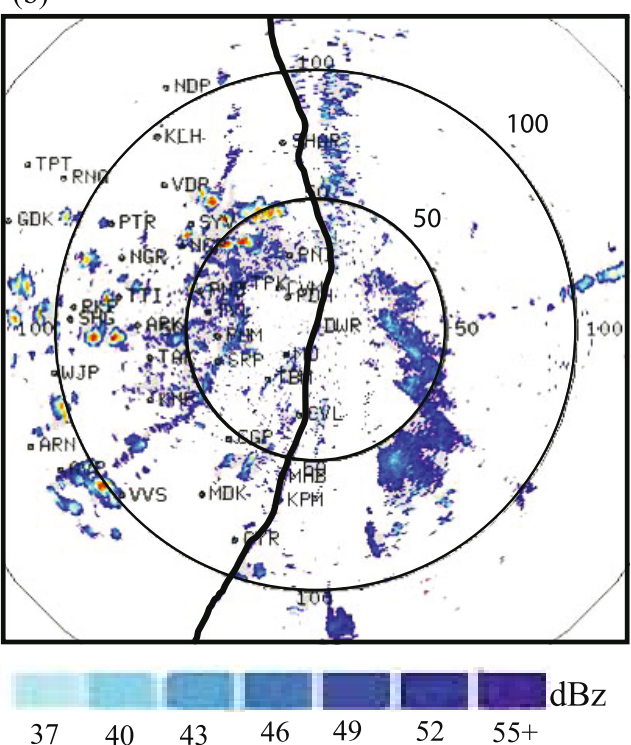

Figure 3. (a) Doppler Weather Radar (DWR) imagery from site located along the coast of Chennai showing the sea breeze front on 27 June 2003 at 15:30 IST. (b) Radar image valid at 16:00 IST on 28 June 2003 showing the location of the sea breeze front and isolated regions of precipitation.

Inland penetration of the sea breeze front along the Chennai coast can be observed in radar imagery of the maximum projection of radar return signal in $\mathrm{dBz}$ (Suresh and Bhatnagar 2004). The location of a sea breeze front over Chennai on 27 June 2003 at 15:30 IST was observed by the maximum projection of radar return signal as shown in figure 3(a). Location of the radar site along the coast within the Chennai metro limits was shown earlier in figure 1(b). Presence of a sea breeze front was observed well inland of the Chennai coast as a narrow line of weak reflectivity values around 13 to $19 \mathrm{dBz}$. Inland penetration of the sea breeze front along the Chennai coast is greatest during the southwest monsoon season (June-September) with an average of around $20 \mathrm{~km}$, though penetration up to $100 \mathrm{~km}$ has been observed (Suresh 2007). The sea breeze has moved approximately $30 \mathrm{~km}$ inland over the urban region of Chennai, while to the north of the urban area, the sea breeze has moved approximately $40 \mathrm{~km}$ inland. Pulicat Lake is located along the coast just north of Chennai and may explain why the sea breeze front was observed further inland north of the city. Presence of the sea breeze front and higher radar reflectivity values due to rainfall were observed over the Chennai region at 16:00 IST on 28 June 2003 (figure 3b). The sea breeze front was around $35 \mathrm{~km}$ inland just west of Chennai while further to the south the sea breeze front had penetrated nearly $50 \mathrm{~km}$ inland. Isolated regions of light rainfall were located in close proximity to the sea breeze front where highest amounts of low-level convergence were present.
Highest radar estimated rainfall totals during the simulation period occurred during the late hours of 28 June and the early morning of 29 June 2003 along the western region of Chennai and approximately $70 \mathrm{~km}$ to the southwest of the city. Total radar estimated rainfall over the Chennai region valid from 14:30 IST on 28 June until 02:30 IST on 29 June 2003 is shown in figure 4 . Rainfall amounts exceeding $100 \mathrm{~mm}$ were estimated over a large region along the southwest region of Chennai. Further inland to the west, total rainfall amounts decreased sharply to around $40 \mathrm{~mm}$. A large region of rainfall amounts greater than $100 \mathrm{~mm}$ was also observed about $75 \mathrm{~km}$ to the southwest of Chennai. The locations of highest rainfall totals correspond to the track of convective cells that moved from west to east as the southwest monsoon flow began to dominate along the coast.

\section{Discussion of results}

\subsection{Control run}

Wind speeds over the city of Chennai during the simulation period appear to be heavily dependant on the wind direction. Low wind speeds are observed over the city when the wind direction is from the south/west and moving over land. Wind speeds are higher when the wind direction is from the east and the airmass is transported from over water. A time series of observed $10 \mathrm{~m}$ wind speeds (hollow diamond data points) measured over the Meenambakkam Airport from 06:00 IST on 27 


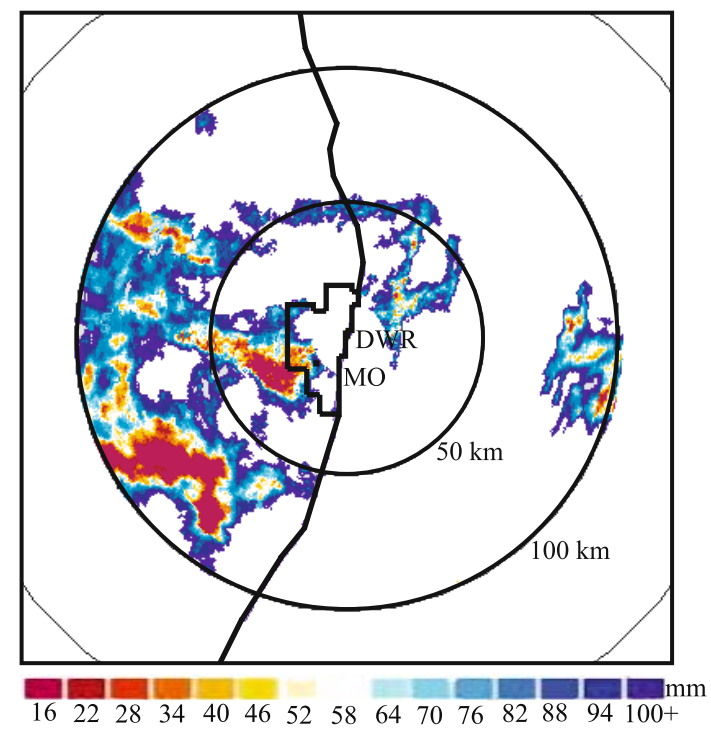

Figure 4. Accumulated radar estimated rainfall along the Chennai coast valid from 14:30 IST on 28 June until 02:30 IST on 29 June 2003.

June to 17:00 IST on 29 June 2003 are shown in figure 5(a). Observed wind speeds range from 1 to $8 \mathrm{~m} \mathrm{~s}^{-1}$ during this period. Highest wind speeds are observed at Meenambakkam during the late afternoon when the easterly winds caused by the sea breeze circulation. The lowest wind speeds are observed during the night and the early morning most likely related to the presence of the nocturnal boundary layer. Simulated wind speeds (solid) typically range from 1.0 to $4.5 \mathrm{~m} \mathrm{~s}^{-1}$ during the simulation period. The model is able to simulate weaker winds during the night and stronger winds during the afternoon for the first day of the simulation. However, wind speeds with a value of around $3.0 \mathrm{~m} \mathrm{~s}^{-1}$ are simulated for the rest of the period. The simulated wind speed is more representative of the preceding hour while the observed wind speed is measured over only a few minutes of averaging time.

Since Chennai is located along the east coast of India, large diurnal variations in wind direction are observed due to the development of the sea breeze. Observed wind directions at $10 \mathrm{~m}$ height above ground (hollow data points) from 06:00 IST on 27 June to 17:00 IST on 29 June 2003 are shown in figure $5(\mathrm{~b})$. Wind directions were from the southwest to west during the late evening and night-time hours due to the background monsoon flow. As the sea breeze develops during the morning hours, a wind shift to southeasterly flow occurs and was observed on all the three days of the simulation period. The southeast wind direction turned back to southwesterly by late evening hours as the sea breeze weakened. Simulated $10 \mathrm{~m}$ wind directions (solid) are shown in figure 5(b).
Simulated wind directions were from around $240^{\circ}$ to $300^{\circ}$ during the night-time and early morning hours during the simulation period. A wind shift to around $120^{\circ}$ was simulated on all three days due to the developing sea breeze. The model also simulates the transition of onshore flow to offshore flow during the late evening hours typically around midnight. It was during the transition to offshore flow around midnight when the majority of rainfall was observed over Chennai.

The sea breeze along the east coast of India influences the air temperature over Chennai. Observed $2 \mathrm{~m}$ dry bulb temperatures (hollow data points) over the Meenambakkam Airport from 06:00 IST on 27 June to 17:00 IST on 29 June 2003 are shown in figure $5(\mathrm{c})$. Temperatures during the night are around $28^{\circ}$ to $30^{\circ} \mathrm{C}$ except for during the night on 29 June when the air was cooled to around $24^{\circ} \mathrm{C}$ by precipitation. Peak air temperatures during the day are around $37^{\circ} \mathrm{C}$ and occur just after midday. The highest temperatures occur around noon just before the developing sea breeze begins to transport cooler air from over the ocean. Sea surface temperatures (SST) over the Bay of Bengal just offshore of Chennai were around $29^{\circ}$ to $30^{\circ} \mathrm{C}$ during the simulation period. MM5 simulated dry bulb temperatures (solid data point) at $2 \mathrm{~m}$ height above ground are also shown in figure 5(c). The model was able to simulate the diurnal temperature change of $8^{\circ} \mathrm{C}$ on 27 and 28 June 2003 reasonably well. Timing of peak temperatures occurring just after mid-day due to the influence of the sea breeze was also simulated. Observed rain cooled temperatures during the night on 29 June were not simulated by the model because no significant precipitation was modeled over or near Chennai at that time. Hence, simulated and observed temperatures during the night of 29 June differ by around $4^{\circ} \mathrm{C}$. Daytime temperatures on 29 June are also overestimated due to no rain simulated overnight. Except for the morning of 29 June, the model was able to simulate the diurnal changes in temperature and the influence of the sea breeze on afternoon temperatures.

Atmospheric soundings from the Meenambakkam Airport provide additional data to validate the model simulation. Observed (solid line) and simulated (dashed line) potential temperature profiles over Chennai valid at 17:00 IST on 28 June 2003 are shown in figure 6 (a). The observed surface potential temperature was $306 \mathrm{~K}$ while the simulated temperature was $304 \mathrm{~K}$. A mixed layer up to a height of $700 \mathrm{~m}$ was simulated while the observations did not show a well mixed layer probably due to coarse resolution of the sounding. Both observed and modeled potential temperatures increased to $324 \mathrm{~K}$ at a height of $5000 \mathrm{~m}$. Modeled water vapor mixing ratios were too low at 

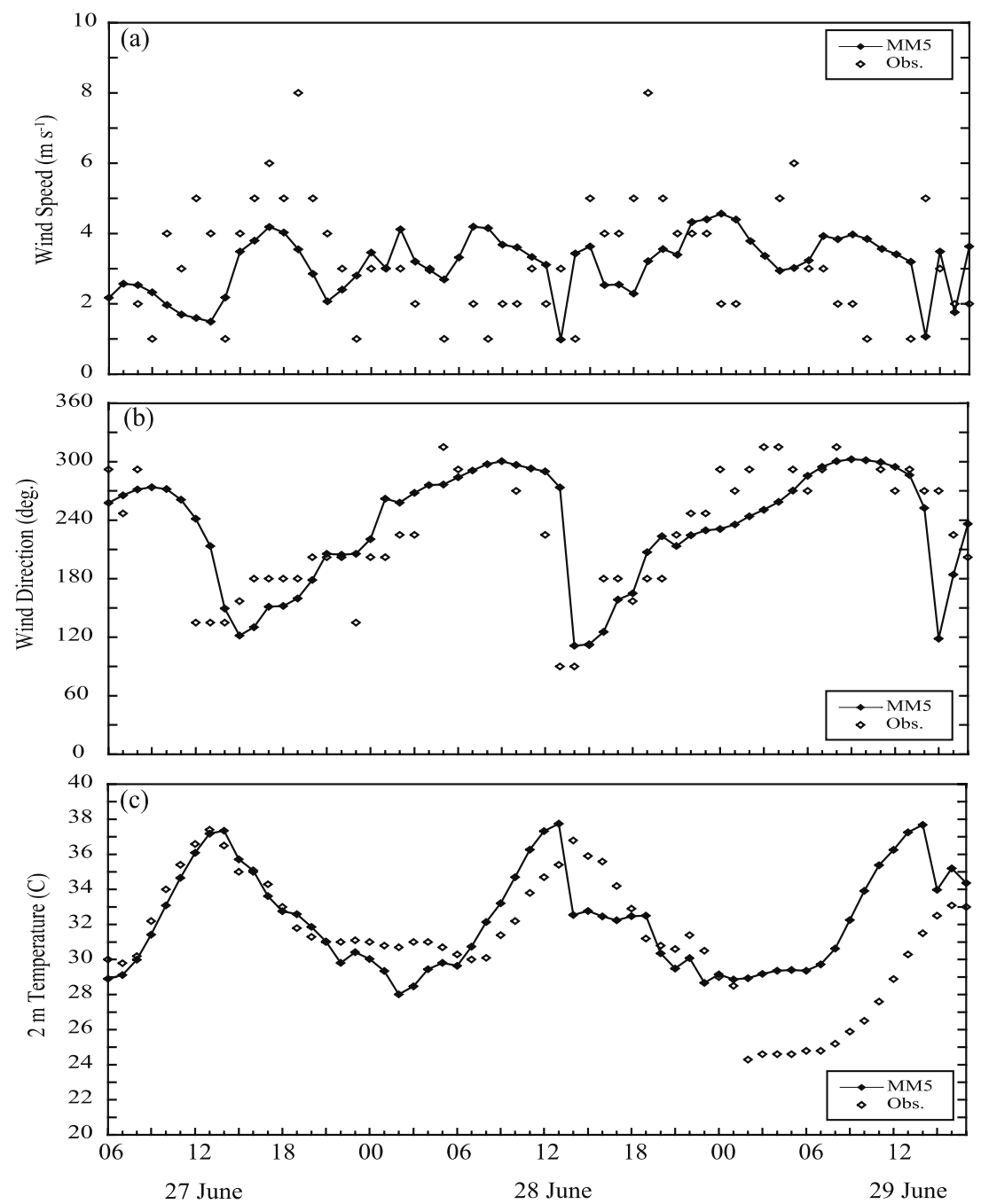

Figure 5. (a) Comparison of MM5 simulated $10 \mathrm{~m}$ wind speed and observations from the Meenambakkum Airport from 05:00 IST on 27 June to 17:00 IST on 29 June 2003. (b) Same as (a) but for $10 \mathrm{~m}$ wind direction. (c) Same as (a) but for $2 \mathrm{~m}$ dry bulb air temperature.

17:00 IST on 28 June as shown in figure 6(b). Simulated water vapor mixing ratio was $3 \mathrm{~g} \mathrm{~kg}^{-1}$ lower at the surface than the observed values. The simulated mixing ratio was lower than the observed values by typically $2 \mathrm{~g} \mathrm{~kg}^{-1}$ up to a height of $3000 \mathrm{~m}$. Underestimation of the amount of water vapor in the lower atmosphere by the model could have significant impacts on the amount of rainfall predicted along the Chennai coast. Wind speed values of 3 to $4 \mathrm{~m} \mathrm{~s}^{-1}$ were observed and simulated up to a height of $700 \mathrm{~m}$ as shown in figure 6(c). A decrease in wind speed was observed and simulated above the mixed layer. Maximum observed wind speed value of $11 \mathrm{~m} \mathrm{~s}^{-1}$ was observed at a height of $2200 \mathrm{~m}$ while the maximum simulated value was $9.0 \mathrm{~m} \mathrm{~s}^{-1}$ occurring at a height of $2800 \mathrm{~m}$. The model accurately simulated the decrease in wind speed to around $3.0 \mathrm{~m} \mathrm{~s}^{-1}$ at a height of $5000 \mathrm{~m}$. Presence of a sea breeze was again evident in the observed wind direction profile over Chennai at
17:00 IST as shown in figure 6(d). Wind directions at the surface were from $140^{\circ}$, indicating onshore flow associated with the sea breeze. Onshore flow was observed up to a height of $800 \mathrm{~m}$, where the winds turned to westerly flow. Simulated wind directions at the surface were from $130^{\circ}$ and agree with the observation of onshore flow. Simulated wind directions were onshore up to a height of $1000 \mathrm{~m}$. Above $1000 \mathrm{~m}$, simulated wind directions became west to northwesterly, which agrees well with the observations. The model was able to simulate the development of the sea breeze during the afternoon of 28 June 2003.

Large temperature gradients between air temperatures over land and over the Bay of Bengal occur along the Chennai coast during the daytime. Strong sea breezes develop along the Chennai coast due to the large contrast (about $10^{\circ} \mathrm{C}$ ) in near surface air temperatures between land and ocean. Simulated $2 \mathrm{~m}$ dry bulb temperatures and $10 \mathrm{~m}$ 

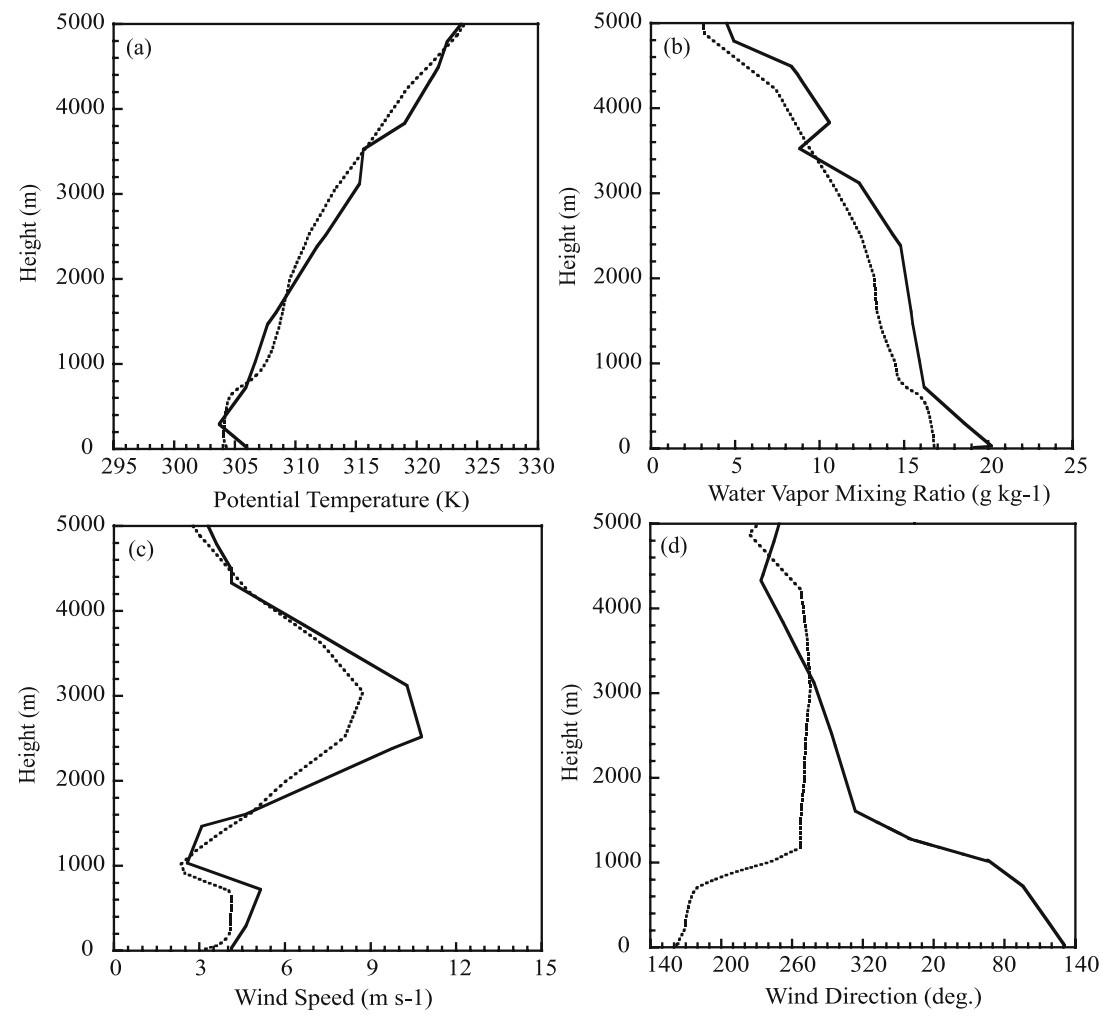

Figure 6. (a) Comparison of a model simulated (dashed) and observed (solid) potential temperature profile valid 28 June 2003 at 12:00 UTC (17:30 LT). (b) Same as (a) but for water vapor mixing ratio profile. (c) Same as (a) but for wind speed profile. (d) Same as (a) but for wind direction profile.

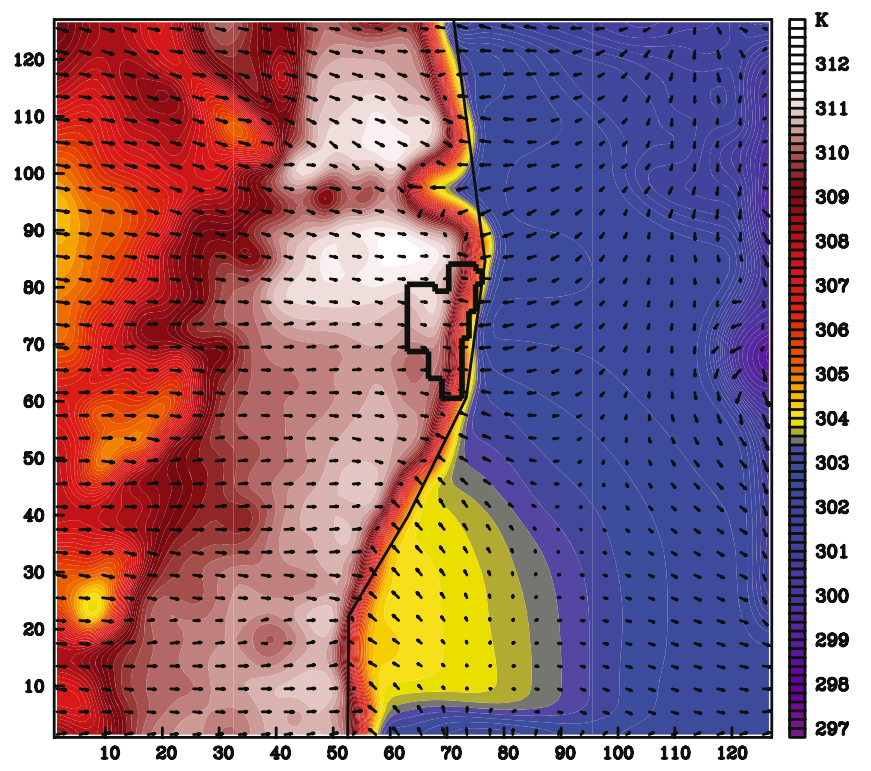

Figure 7. Simulated $2 \mathrm{~m}$ dry bulb temperatures and $10 \mathrm{~m}$ horizontal wind vectors valid 13:00 IST on 28 June 2003. The $x$ and $y$ axis represent model grid points. A temperature gradient of $10 \mathrm{~K}$ was simulated along the Chennai coast. Maximum $10 \mathrm{~m}$ wind speed were around $8.0 \mathrm{~m} \mathrm{~s}^{-1}$.

horizontal wind vectors valid at 13:00 IST on 28 June 2003 are shown in figure 7 . Air temperatures $30 \mathrm{~km}$ inland from the coast were in the range of
310 to $312 \mathrm{~K}$ while temperatures just offshore were between 302 and $303 \mathrm{~K}$. An air temperature contrast of $10 \mathrm{~K}$ was simulated over a distance of $30 \mathrm{~km}$ along the coast. This large temperature gradient led to the development of a sea breeze circulation and the onshore flow was simulated at $10 \mathrm{~m}$ height. Onshore wind speeds associated with the sea breeze along the coast were near $8.0 \mathrm{~m} \mathrm{~s}^{-1}$. A region of slightly warmer $2 \mathrm{~m}$ temperatures were simulated over the ocean just south of Chennai possibly due to the coarse initialization of the sea surface temperature.

Strength of the sea breeze and the resulting inland penetration of the sea breeze front vary daily along the east coast of India. Simulated $10 \mathrm{~m}$ horizontal wind vectors and u-components of the horizontal wind in color contours valid at 15:30 IST on 27 June 2003 are shown figure 8(a). Onshore flow associated with the sea breeze was typically around $2.0 \mathrm{~m} \mathrm{~s}^{-1}$ along the coast near Chennai on 27 June. The sea breeze front was located around 20 to $25 \mathrm{~km}$ inland along the Chennai coast. To the north of Chennai, the geography of Pulicat Lake has influenced the symmetry of the sea breeze front curvature. The inland extent of sea breeze and the curvature of the sea breeze front north of Chennai are in good agreement with radar imagery of the sea breeze front shown earlier in 


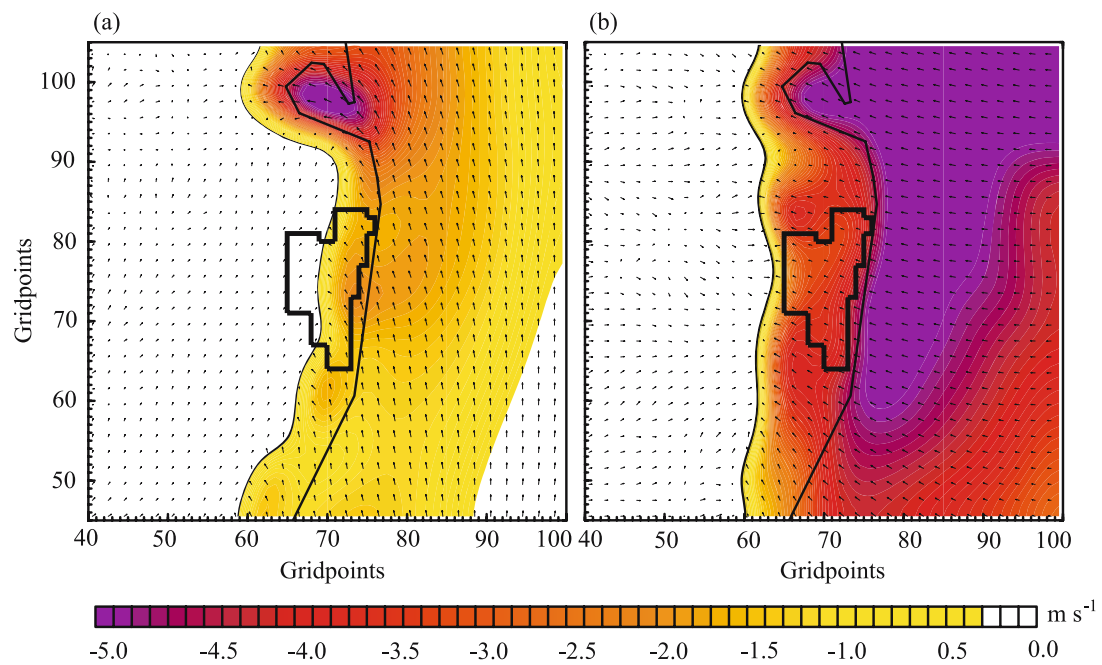

Figure 8. (a) Simulated $10 \mathrm{~m}$ wind vectors with onshore flow (u-component) in contours valid at 15:30 IST on 27 June 2003. The sea breeze front is located along the leading edge of onshore flow. Outline of the Chennai metro area is shown in black. (b) Same as (a) but valid at 15:30 IST on 28 June 2003.

figure 3(a). Stronger onshore flow was simulated along the coast at 15:30 IST on 28 June 2003 with values near $5.0 \mathrm{~m} \mathrm{~s}^{-1}$ (figure $8 \mathrm{~b}$ ). Increased onshore flow resulted in the sea breeze front penetrating inland to a distance of around 35 to $40 \mathrm{~km}$ along the Chennai coast. Effects of Lake Pulicat and the urban roughness effect on the symmetry of the inland sea breeze front were minimal on 28 June 2003 due to enhanced onshore flow.

Upward (positive) vertical motion occurs along the leading edge of the sea breeze front as it moves inland. The location of a sea breeze cross section along the Chennai coast is shown in figure 9(a) as a line extending from $\mathrm{X}$ to $\mathrm{Y}$. Simulated circulation vectors $(u, w)$ with onshore flow in color contours valid at 15:00 IST on 28 June 2003 are shown in figure $9(\mathrm{~b})$. Onshore flow was simulated up to a height of $700 \mathrm{~m}$ along the coast, which agrees with radiosonde observations shown earlier. The maximum onshore wind values of $8.0 \mathrm{~m} \mathrm{~s}^{-1}$ occur just offshore at a height of $100 \mathrm{~m}$ above ground. A region of positive vertical velocity was simulated along the leading edge of the sea breeze front. Maximum vertical velocity ahead of the sea breeze front was $1.4 \mathrm{~m} \mathrm{~s}^{-1}$ and occurred at a height of $1500 \mathrm{~m}$.

Large convergence zone develops as the sea breeze front propagates inland. Simulated $10 \mathrm{~m}$ horizontal wind vectors and $10 \mathrm{~m}$ convergence valid 07:00 IST on 28 June 2003 are shown in figure 10(a). Westerly flow with maximum values of $12.0 \mathrm{~m} \mathrm{~s}^{-1}$ was dominating throughout the model domain since the sea breeze has not yet developed. No region of substantial convergence was simulated due to the absence of onshore flow associated with the sea breeze. By 10:00 IST on 28 June
2003, weak onshore flow was simulated along the coast with a wind speed of few meters per second as shown in figure 10(b). The onshore flow was the result of the developing sea breeze. Small regions of localized convergence were simulated along the sea breeze front with maximum values of $42 \times 10^{-5} \mathrm{~s}^{-1}$. Onshore flow has strengthened to nearly $7.0 \mathrm{~m} \mathrm{~s}^{-1}$ by 13:00 IST as shown in figure 10(c). A well developed sea breeze circulation was simulated with onshore flow extending well offshore. Along the sea breeze front, a band of coastal convergence was simulated along the entire model domain. The width of the convergence band was generally $20 \mathrm{~km}$. Maximum values within the convergence zone were $50 \times 10^{-5} \mathrm{~s}^{-1}$. The band of convergence is not prominent at 16:00 IST due to the outflow associated with the development of convection as shown in figure 10(d). Onshore flow was still simulated and has strengthened to around $9.0 \mathrm{~m} \mathrm{~s}^{-1}$ just offshore. Convergence zones overland were more sporadic with maximum convergence values of $50 \times 10^{-5} \mathrm{~s}^{-1}$ occurring over only a small region.

Convection is frequently initiated by convergence associated with the sea breeze circulation during the southwest monsoon along the southeast coast of India. Large amounts of rainfall occur near Chennai due to sea breeze induced convection (Simpson et al 2005). Simulated 24-hour rainfall amounts from 05:00 IST on 28 June until 05:00 IST on 29 June 2003 and the corresponding observed rainfall are shown in figure 11. Range rings are shown in figure 11 to provide a reference scale with the radar estimated rainfall shown earlier in figure 4. Rainfall is simulated over a large region well inland. Precipitation totals were typically in the 

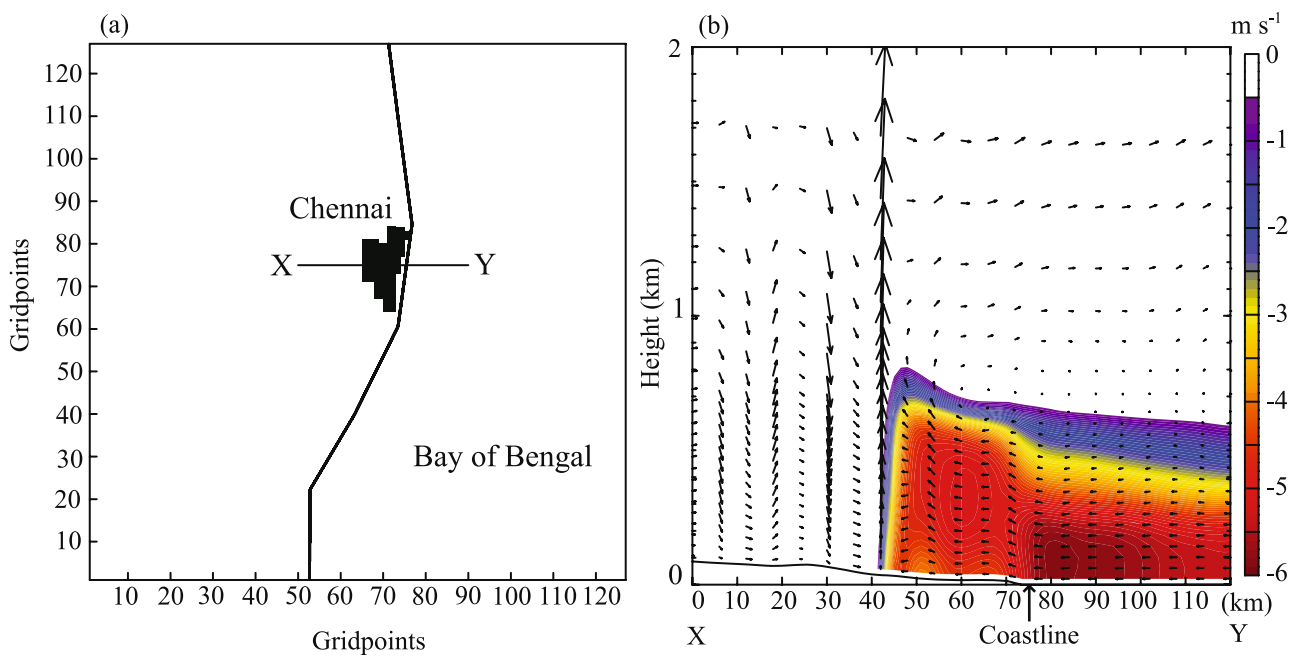

Figure 9. (a) Map showing the location of a sea breeze cross section over Chennai and the Bay of Bengal. (b) Simulated circulation vectors $(u, w)$ with the onshore values of the u-component shown in the color contour valid at 15:00 IST on 28 June 2003. Maximum onshore wind speed was $8.0 \mathrm{~m} \mathrm{~s}^{-1}$ while the max vertical velocity was $1.4 \mathrm{~m} \mathrm{~s}^{-1}$. The absicca represents distance $(\mathrm{km})$ running west to east along the cross section.
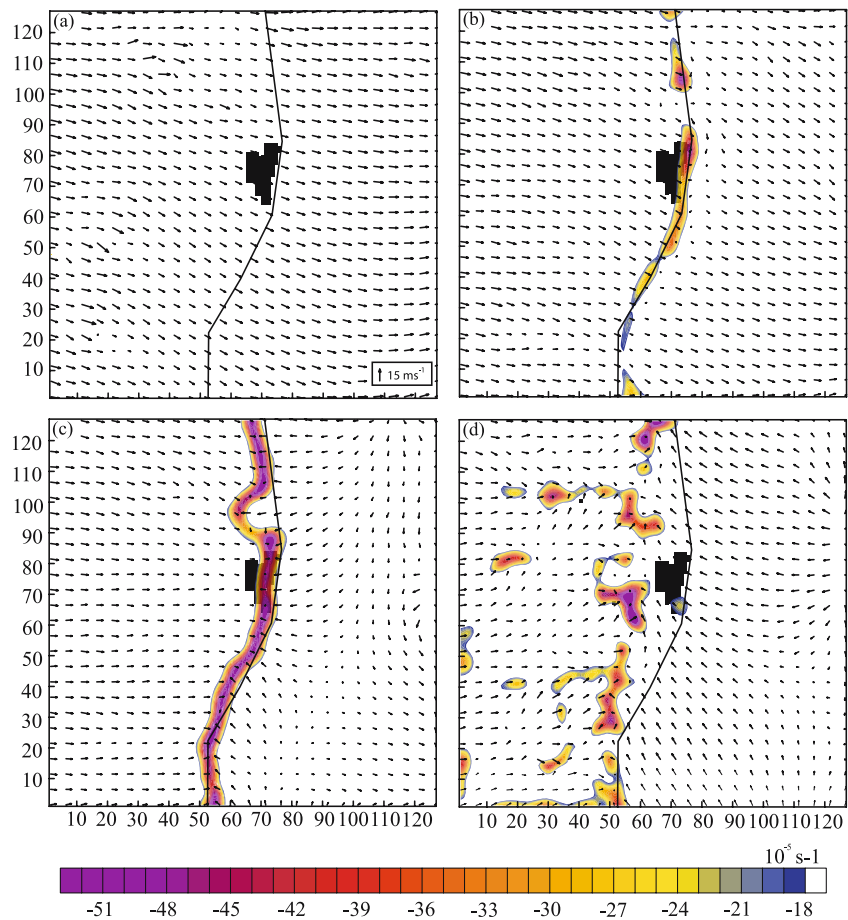

Figure 10. (a) Simulated $10 \mathrm{~m}$ horizontal wind vectors and $10 \mathrm{~m}$ convergence valid 07:00 IST on 28 June. (b) Same as (a) but valid at 10:00 IST on 28 June. (c) Same as (a) but at 13:00 IST on 28 June. (d) Same as (a) but valid at 16:00 IST on 28 June 2003.

range of 10 to $20 \mathrm{~mm}$ with higher amounts occurring over only a small region. Maximum simulated rainfall was around $50 \mathrm{~mm}$, which occurred well inland to the west of Chennai. The model was unable to simulate precipitation near the coast over Chennai where rainfall amounts of up to $100 \mathrm{~mm}$ were observed. However, the location of simulated inland rainfall compares reasonably well

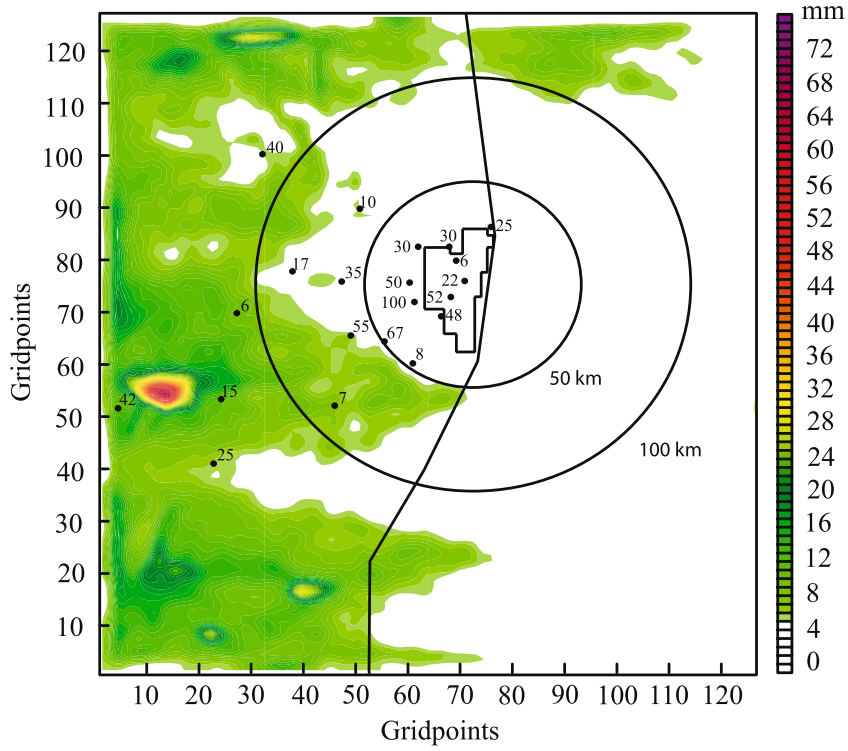

Figure 11. Simulated total rainfall amounts $(\mathrm{mm})$ from 05:00 IST on 28 June until 05:00 IST on 29 June 2003. Corresponding observed rainfall amounts $(\mathrm{mm})$ are overlaid. Range rings are also shown with a scale corresponding to that of figure 4 .

with the location of observed precipitation. Rainfall amounts of only 5 to $10 \mathrm{~mm}$ were simulated to the southwest of Chennai. The model was able to simulate the distribution of rainfall related to the sea breeze during the daytime but was unable to accurately simulate the location and the magnitude of large rainfall that occurred during the night.

\subsection{Urban effects}

Larger roughness over urban areas cause more friction and result in a decrease of near surface 


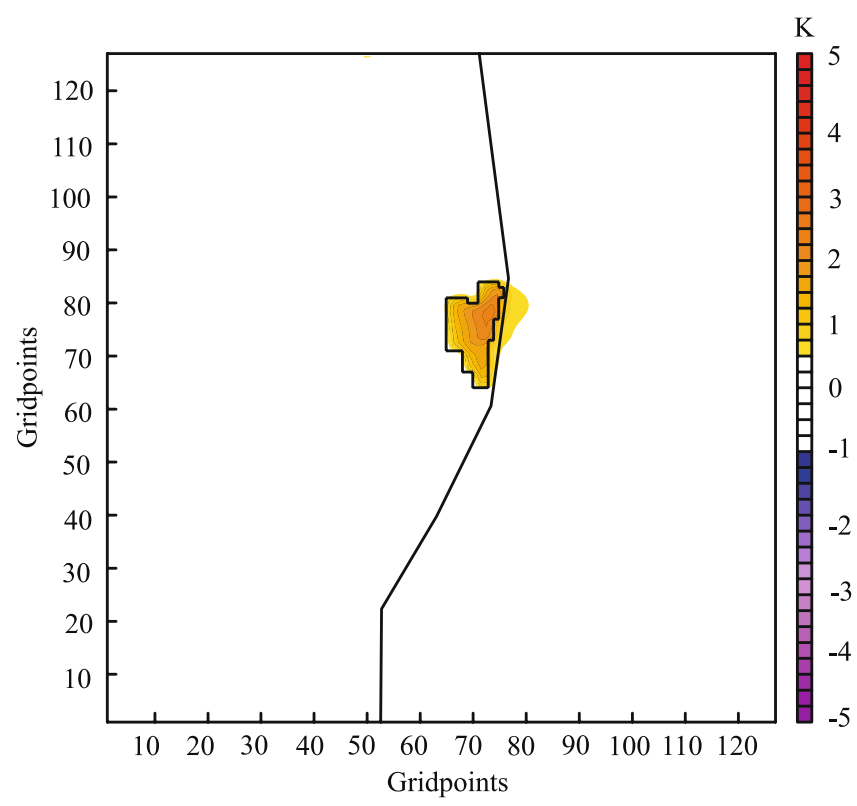

Figure 12. URBAN minus NOURBAN simulated $2 \mathrm{~m}$ air temperatures valid at 05:00 IST on 28 June 2003. Metropolitan limits of Chennai are shown in black. Temperatures at $2 \mathrm{~m}$ are up to $3 \mathrm{~K}$ warmer over Chennai than the surrounding rural regions due to anthropogenic heating.

wind speeds. Anthropogenic heating over urban regions increases near surface air temperatures and decreases stability. To study the urban effect of Chennai on the sea breeze circulation and precipitation, an MM5 simulation was run excluding the urban region of Chennai, which will be referred to as the NOURBAN simulation. The control run with the urban land use of Chennai included will be referred to as the URBAN simulation throughout the following discussion. The urban land use of the Chennai region was replaced with irrigated cropland and pasture for the NOURBAN simulation. Irrigated cropland and pasture land was used since it is the primary land use type surrounding the Chennai region. By modifying the land use map, the roughness length over Chennai was reduced from 0.80 to $0.15 \mathrm{~m}$, the albedo was increased from 0.15 to 0.18 , and the surface emissivity was increased from 0.880 to 0.985 . Changing the Chennai urban land use to cropland increased surface thermal inertia and surface moisture availability over the region while it decreased soil heat capacity.

The near-surface air temperature difference caused by the urban land use of Chennai does not extend far from the city limits during the night. URBAN minus NOURBAN simulated $2 \mathrm{~m}$ dry bulb temperatures $(\mathrm{K})$ valid at 05:00 IST on 28 June 2003 are shown in figure 12 . The net effect of the urban land use was to increase $2 \mathrm{~m}$ air temperatures over Chennai by roughly 2 to $3 \mathrm{~K}$. Maximum increase in $2 \mathrm{~m}$ temperature by the urban land use was $3.0 \mathrm{~K}$ over a small region near the coastline. A small increase in air temperatures was simulated up to $15 \mathrm{~km}$ offshore due to the transport of warmer city airmass over the ocean by strong southwesterly monsoon flow. By increasing near surface air temperatures over Chennai, the urban effect results in a larger temperature gradient along the coast between the air temperatures over land and ocean.

Urban land use in Chennai reduces wind speeds over the city due to higher surface roughness. However, the urban land use can have an opposite effect on wind speeds associated with the sea breeze just offshore. URBAN minus NOURBAN simulated

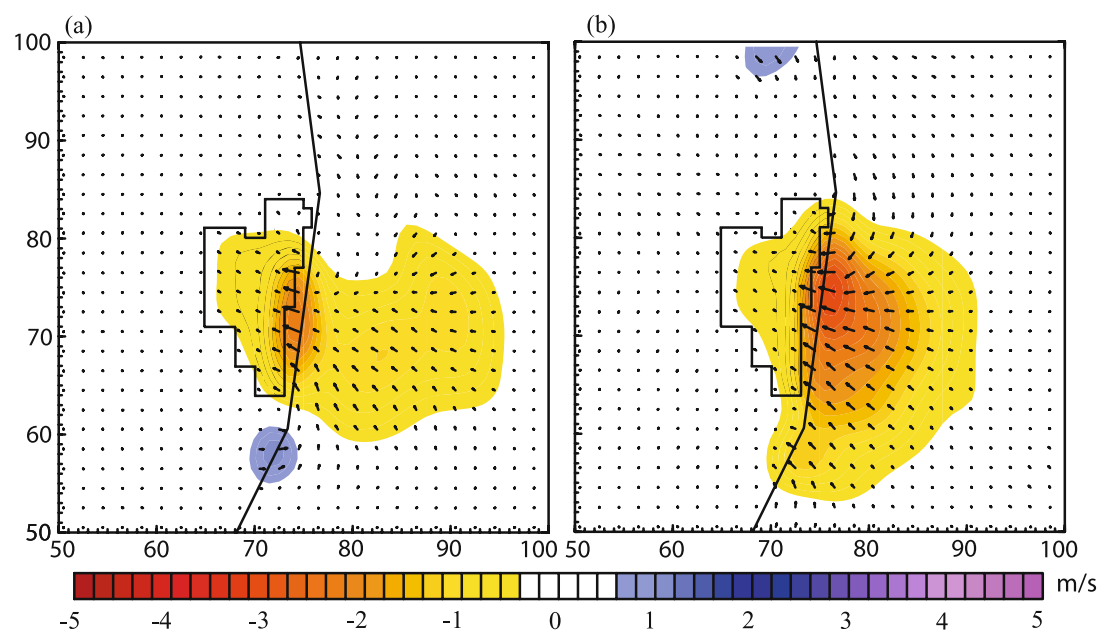

Figure 13. (a) URBAN minus NOURBAN simulated $10 \mathrm{~m}$ wind vectors valid at 11:00 IST on 28 June 2003 with the metropolitan limits of Chennai shown in black. Cool color contours correspond to an increase in offshore flow due to urban effects while an increase in onshore flow is indicated by warm colors. Onshore flow is increased by $4.1 \mathrm{~m} \mathrm{~s}^{-1}$ along the coast by the Chennai urban effect. (b) Same as (a) but valid at 11:00 IST on 29 June 2003 with onshore flow increased by a maximum of $4.3 \mathrm{~m} \mathrm{~s}^{-1}$. 
$10 \mathrm{~m}$ horizontal wind vectors valid at 11:00 IST on 28 June 2003 are shown in figure 13(a). Onshore flow associated with the developing sea breeze was enhanced along the Chennai coast by the urban land use. The maximum increase in onshore winds was $4.1 \mathrm{~m} \mathrm{~s}^{-1}$ and occurred just offshore of Chennai. Urban land use enhanced the sea breeze onshore flow by more than $1.0 \mathrm{~m} \mathrm{~s}^{-1}$ up to a distance of $60 \mathrm{~km}$ offshore. An increase in onshore flow occurred because URBAN ground temperatures were typically $4.0 \mathrm{~K}$ warmer over the city than the NOURBAN simulation, which resulted in a larger land-ocean air temperature gradient. Urban effects also increased onshore wind speeds associated with the sea breeze along the Chennai coast at 11:00 IST on 29 June 2003 (figure $13 \mathrm{~b}$ ). The maximum increase in onshore flow was $4.3 \mathrm{~m} \mathrm{~s}^{-1}$, which again occurred just offshore along the coast of Chennai. Enhancement of the sea breeze onshore flow was simulated up to an offshore distance of $45 \mathrm{~km}$.

Onshore flow associated with the sea breeze is increased along the Chennai coast over a large depth due to the urban effect. A cross section through the urban region of Chennai (same as shown in figure 9a) valid at 11:00 IST on 28 June 2003 with URBAN minus NOURBAN circulation vectors $(u, v, w)$ is shown in figure 14(a). Increased onshore flow was simulated along the coast from the surface up to a height of $800 \mathrm{~m}$ due to the urban effect of Chennai. Onshore flow increased by more than $2.0 \mathrm{~m} \mathrm{~s}^{-1}$ over a layer of $400 \mathrm{~m}$ above the surface. Positive vertical motion was also increased by the urban effect near the coast, most likely due to the enhanced wind speeds and more convergence. The maximum increase in vertical velocity was $0.30 \mathrm{~m} \mathrm{~s}^{-1}$ at a height of $900 \mathrm{~m}$ above the surface. The majority of the increase in vertical velocity was isolated to the leading edge of the sea breeze front. Onshore flow associated with the sea breeze was reduced by 2.0 to $3.0 \mathrm{~m} \mathrm{~s}^{-1}$ on the lee side of the city valid at 15:00 IST possibly due to the combined effect of heat island induced pressure gradient and due to urban roughness (figure 14b). Return flow (offshore) aloft associated with the sea breeze circulation was also reduced by around $2.0 \mathrm{~m} \mathrm{~s}^{-1}$ by urban effects. Low-level convergence was enhanced and the maximum positive vertical velocity along the sea breeze front was increased by $1.4 \mathrm{~m} \mathrm{~s}^{-1}$. Increase in upward vertical velocity could be due to the two sea breeze fronts being in different locations.

Changes in the strength of the sea breeze and vertical motion due to urban effects of Chennai are expected to cause changes in precipitation amounts and patterns. URBAN minus NOURBAN simulated precipitation totals from 05:00 IST on 28 June to 05:00 IST on 29 June 2003 are shown in
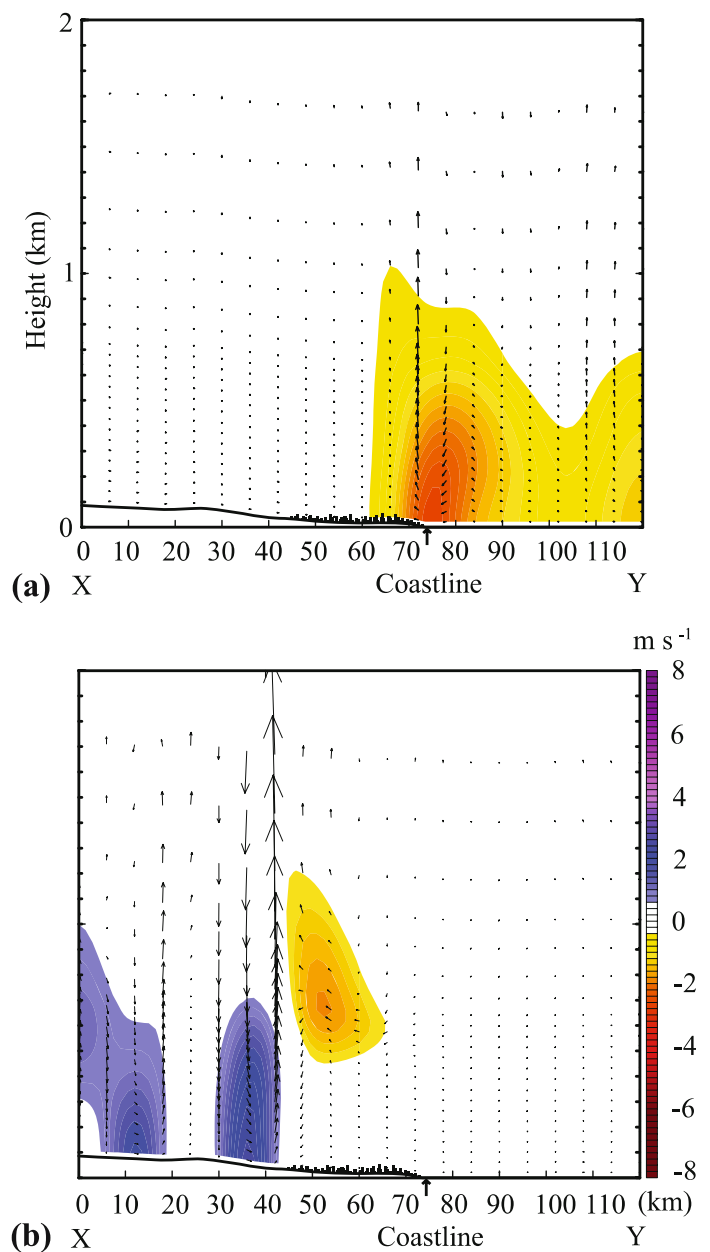

Figure 14. (a) URBAN minus NOURBAN simulated circulation vectors $(u, v, w)$ valid at 11:00 IST on 28 June 2003. The cross section was taken over Chennai and the Bay of Bengal, same as figure 9. Difference in horizontal wind speed between the URBAN and NOURBAN simulations are shown by colour contours. Positive vertical motion was increased by $0.30 \mathrm{~m} \mathrm{~s}^{-1}$ along the leading edge of the sea breeze front by the Chennai urban effect. (b) Same as (a) but at 15:00 IST with a maximum increase in vertical velocity of $1.4 \mathrm{~m} \mathrm{~s}^{-1}$.

figure 15(a). Simulated rainfall totals were influenced by the urban region in two regions downwind of the city. Approximately $140 \mathrm{~km}$ to the southwest of Chennai, there was an increase in rainfall with a decrease in rainfall also nearby. Rainfall amounts in this region were shifted to the southwest possibly due to the urban effects. However, no direct cause and effect relationship between the urban area and precipitation modification can be made without a larger dataset of numerical simulations. A net gain in rainfall totals was observed $160 \mathrm{~km}$ to the west of Chennai. Rainfall amounts were increased by the urban effect by up to $25 \mathrm{~mm}$ over an area of $400 \mathrm{~km}^{2}$. The increase in simulated rainfall amounts due to the Chennai urban effect indicates that urban regions along the coast can influence convergence patterns and rainfall totals 


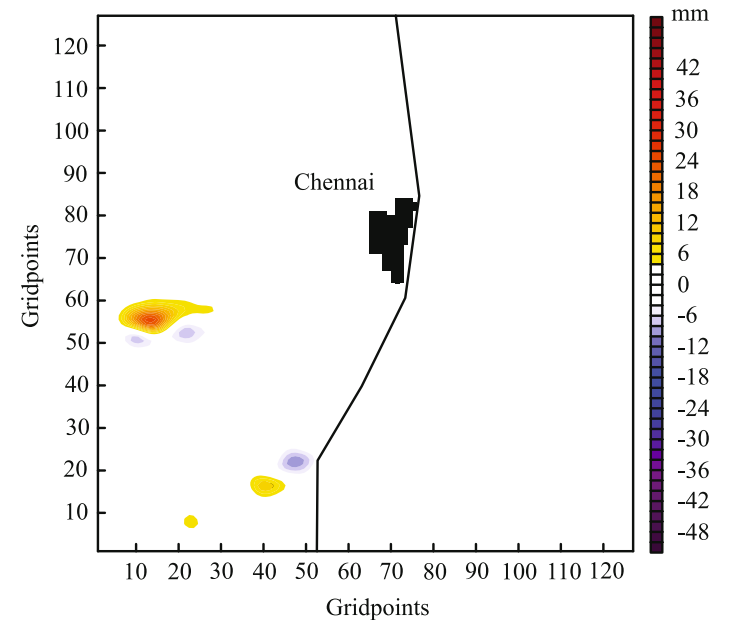

Figure 15. URBAN minus NOURBAN simulated total rainfall from 05:00 IST on 28 June until 05:00 IST on 29 June 2003. Metropolitan limits of Chennai are shown in black.

well inland. However, it is important to point out that the control simulation could not produce precipitation observed close to Chennai during night-time.

\section{Conclusions}

Observations show a well developed sea breeze circulation along the southeastern coast of Chennai on 28 June 2003. A numerical model is able to simulate the development and timing of the sea breeze propagation along the coast. Predicted diurnal variation of near surface air temperatures over Chennai agrees well with observations during the simulation period. A maximum temperature gradient of $10 \mathrm{~K}$ is simulated along the Chennai coast. Maximum simulated $10 \mathrm{~m}$ wind speed values associated with the sea breeze are $9.0 \mathrm{~m} \mathrm{~s}^{-1}$ and occur just offshore. Regions of convergence are simulated over land along the leading edge of the onshore flow associated with the sea breeze. Positive vertical velocities of $1.4 \mathrm{~m} \mathrm{~s}^{-1}$ are simulated in advance of the sea breeze front. Rainfall amounts of $100 \mathrm{~mm}$ are observed in association with the inland propagation of the sea breeze front. The model is able to simulate daytime precipitation resulting from the influence of sea breeze convergence. However, the model is not able to accurately simulate the location of high rainfall amounts observed over Chennai during the night-time. Possible reasons for the model's inability to simulate night-time rainfall along the coast include premature dissipation of inland clouds and the need for better cloud-radiation parameterization.

Anthropogenic heating over the urban region of Chennai increased the near surface air temperature by $3.0 \mathrm{~K}$. Onshore flow associated with the daytime sea breeze was increased by $4.0 \mathrm{~m} \mathrm{~s}^{-1}$ due to the larger temperature gradient along the Chennai coast caused by the urban effect. Changes in convergence patterns and positive vertical motion caused by the urban land use along the coast increased rainfall totals by $25 \mathrm{~mm}$ over a large region to the west of Chennai.

\section{Acknowledgements}

This work was funded by the Atmospheric Sciences Division, National Science Foundation under grants ATM-0233780 and ATM-0342691. Doppler weather radar imagery and surface meteorological data were provided by the India Meteorological Department. We thank two anonymous reviewers for their valuable comments and suggestions.

\section{References}

Atkins N and Wakimoto R 1997 Influence of the synopticscale flow on sea breezes observed during CaPE; Mon. Wea. Rev. 125 2112-2130.

Baker R, Barry L, Boone A, Tao W K and Simpson J 2001 The influence of soil moisture, coastline curvature, and land-breeze circulations on sea-breeze initiated precipitation; J. Hydromet. 2 193-211.

Blanchard D and Lopez R 1985 Spatial patterns of convection in south Florida; Mon. Wea. Rev. 113 1282-1299.

Boybeyi Z and Raman S 1992 A three-dimensional numerical sensitivity study of convection over the Florida peninsula; Bound. Layer Meteor. 60 325-359.

Braham R, Semonin R G, Auer A H, Changnon Jr S A and Hales J M 1981 Summary of urban effects on clouds and rain. METROMEX: A Review and Summary; Meteor. Monogr. 40 141-152.

Changnon S A 1979 Rainfall changes in summer caused by St. Louis; Science 205 402-404.

Changnon S A, Semonin R G, Auer A H, Braham R R and Hales J 1981 METROMEX: A Review and Summary; Meteor. Monogr. Amer. Meteor. Soc. $40181 \mathrm{pp}$.

Changnon S A, Shealy R T and Scott R W 1991 Precipitation changes in fall, winter, and spring caused by St. Louis; J. Appl. Meteor. 30 126-134.

Chen F and Dudhia J 2001 Coupling an advanced landsurface/hydrology model with the Penn State/NCAR MM5 modeling system. Part I: Model implementation and sensitivity; Mon. Wea. Rev. 129 $569-585$.

Craig K and Bornstein R 2002 MM5 simulation of urban induced convective precipitation over Atlanta; Preprints, Fourth Conf. on the Urban Environment, Norfolk, VA, Amer. Meteor. Soc., 5-6.

Gilliam R, Raman S and Niyogi D V 2004 Observational and numerical study on the influence of large-scale flow direction and coastline shape on sea-breeze evolution; Bound. Layer Meteor. 111 275-300.

Grell G A, Dudhia J and Stauffer D R 1994 A description of the fifth-generation Penn State/NCAR Mesoscale Model (MM5); NCAR Tech. Note NCAR/TN-398+STR, $122 \mathrm{pp}$.

Hjemfelt M R 1982 Numerical simulation of the effects of St. Louis on mesoscale boundary layer airflow and 
vertical motion: Simulations of urban vs. non-urban effects; J. Appl. Meteor. 21 1239-1257.

Hong S Y and Pan H L 1996 Nonlocal boundary layer vertical diffusion in a medium-range forecast model; Mon. Wea. Rev. 124 2322-2339.

Huff F A and Vogel J L 1978 Urban, topographic and diurnal effects on rainfall in the St. Louis region; J. Appl. Meteor. $17565-577$.

Kusaka H, Kimura F, Hirakuchi H and Mitzutori M 2000 The effects of land use alteration on the sea breeze and daytime heat island in the Tokyo metropolitan area; J. Meteorol. Soc. Japan 78 405-420.

McPherson R D 1970 A numerical study of the effect of a coastal irregularity on the sea breeze; J. Appl. Meteor. 9 $767-777$.

Ohashi Y and Kida H 2002 Local circulations developed in the vicinity of both coastal and inland urban areas: Numerical study with a mesoscale atmospheric model; J. Appl. Meteorol. 41 30-45.

Pielke R 1974 A three-dimensional numerical model of the sea breezes over south Florida; Mon. Wea. Rev. 102 $115-139$.

Pielke R and Cotton W R 1977 A mesoscale analysis over South Florida for a high rainfall event; Mon. Wea. Rev. $105343-362$.
Rhome J, Niyogi D and Raman S 2003 Assessing seasonal transport and deposition of agricultural emissions in eastern North Carolina, USA; Pure Appl. Geophys. 160 $117-141$.

Simpson M, Warrior H, Raman S, Aswathanarayana P A, Mohanty U C and Suresh R 2007 Sea breeze Initiated Rainfall over the East Coast of India during the Indian Southwest Monsoon; Natural Hazards 42 401-413.

Suresh R and Bhatnagar A K 2004 Unusual hail storms during May 2002 in Chennai and its suburbs - A study using data from a single Doppler Weather Radar; Mausam 55(4) 655-670.

Suresh R 2007 Observation of sea breeze front and its induced convection over Chennai in southern peninsular India using Doppler weather radar; Pure Appl. Geophys. 164 1511-1525.

Vukovich F M and Dunn J W 1978 A theoretical study of the St. Louis heat island: Some parameter variations; J. Appl. Meteor. 17 1585-1594.

Yoshikado H 1992 Numerical study of the daytime urban effect and its interaction with the sea breeze; J. Appl. Meteor. 31 1146-1164.

Yoshikado H 1994 Interaction of the sea breeze with the urban heat islands of different sizes and locations; J. Meteor. Soc. Japan 72 139-142. 